\title{
Using The Student Research Project To Integrate Macroeconomics And Statistics In An Advanced Cost Accounting Course
}

Mahamood M. Hassan, California State University, Fullerton, USA Bill N. Schwartz, Retired Professor of Accounting, USA

\begin{abstract}
This paper discusses a student research project that is part of an advanced cost accounting class. The project emphasizes active learning, integrates cost accounting with macroeconomics and statistics by "learning by doing" using real world data. Students analyze sales data for a publically listed company by focusing on the company's growth rates in sales, and their growth rates in real sales by adjusting for inflation using the various consumer price indices or producer price indices that are available, and regressing the sales growth rates against macroeconomic variables such as gross domestic product and the various types of personal consumption expenditure items.
\end{abstract}

Keywords: Active Learning; Sales Forecasting; Regression Analysis; Statistics; Student Research Project

\section{INTRODUCTION}

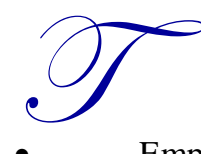

his paper describes a research project one of the authors assigns to his students in an advanced cost accounting class. The instructor initiated the project to accomplish five objectives:

- $\quad$ Emphasize active learning where the students would have to apply their knowledge;

- Integrate cost accounting with material they learned in their macroeconomics (relating sales growth rates to appropriate macroeconomic variables) and statistics courses (expanding the use of regression analysis beyond the area of cost estimation that is covered in the most widely prescribed textbooks in cost accounting and introducing students to various other statistical measures of sales growth rates);

- Gain experience with real-world data and "learn by doing";

- $\quad$ Develop four of the important professional skills included in the AICPA Core Competency Framework (a broad business perspective while leveraging technology, teamwork, written communication, and research skills) (http://www.aicpa.org/interestareas/accountingeducation/resources/pages/corecompetency.aspx); and

- Develop two of the important learning experiences referred to in AACSB Accounting Accreditation Standard \#37 (recording, analysis, and interpretation of historical and prospective financial and nonfinancial information, and design and application of technology to financial and non-financial information management.)

(http://www.aacsb.edu/accreditation/accounting/standards/STANDARDS-accntg-jan2012.pdf)

Students must apply their knowledge of statistics and macroeconomics to estimate sales for a company. The four-year undergraduate degree for accounting majors at a large state university requires students to complete at least two semesters of economics and two semesters of statistics/decision science. The instructor requires his students to analyze sales data for a publically listed company by focusing on the company's growth rates in sales, the company's growth rates in real sales by adjusting for inflation using the various consumer price indices (CPI), or producer price indices (PPI) that are available and regressing the sales growth rates against macroeconomic variables such as gross domestic product (GDP) and the various types of personal consumption expenditure (PCE) items (both in nominal and in real terms). 


\section{LITERATURE REVIEW}

Instructors have used various methods to supplement and expand on accounting textual materials such as research papers, professional and academic journal articles, cases, modules, service-learning projects, guest speakers and the like. Theuri et al. (2011) used a multimedia-based instructional supplement that included a discussion of accounting concepts based on everyday "student-type language to help prepare students for traditional lectures." The authors stated that "the best learning environments exist where there are . . engaged experiences," and that "remembering cannot be simply transmitted from the instructor to the learner because the learner hasn't experienced what the instructor has" (p. 110). In the financial accounting area, Baril et al. (2007) provided a project where students use several models to estimate the value of employee stock options. Briggs and Beams (2012) developed a comprehensive case on securitization of assets for use in a graduate financial, advanced, or second semester intermediate financial accounting class as a take-home assignment. Brenner and Watkins (2011) developed cases for classroom use to help students learn to use the FASB Codification.

In the cost/managerial area, Platt and Towry (2001) designed a case for a cost accounting course to help students develop a greater appreciation for activity-based costing. Stout et al. (2004) prepared and offered a project management module in a graduate managerial accounting course. Dikolli and Sedatole (2004) used a case for students to apply regression analysis to estimate a cost function using historical cost and volume data. Students had to evaluate the usefulness of a cost function for decision making and planning regarding a company's entry into new product markets. Friedman et al. (2006) used an emerging technology in a managerial accounting course. They created a comprehensive case study (The Light) that provided each student with a unique case with an artificial intelligent grading modular, a high-speed feedback modular capable of giving unlimited feedback that was available 24/7, without incurring additional instructor resources. Again, this time in a managerial accounting context, students had engaged experiences that went beyond what the instructor alone could do. Swain et al. (2010) prepared a case for an intermediate cost accounting course so that students could apply concepts such as direct versus indirect costs, variable versus fixed costs, break-even analysis, budgets and variance analysis in a service industry context.

Others went in different directions. Paquette (2005) developed an extended assignment using spreadsheet software to help students calculate growth rates for sales and earnings using historical data from company annual reports. Hoffjan (2005) played a short business game in an advanced management accounting course to emphasize relevant costs, opportunity costs, and transfer prices. The game took three, 75 -minute class meetings to play. Chiang (2008) used service-learning projects in a managerial accounting class to conduct detailed cost analyses. Danvers and Brown (2009) built a model to support planning and decision-making, using cost-volume-profit and benchmarking in an advanced managerial accounting course.

This paper adds to that literature and offers a project that engages experience beyond what the instructor can do. The remainder of this paper includes a description of the advanced cost accounting course, the background for the research project, the project itself, students feedback from responses to a questionnaire collected in spring 2013, reflections on past semesters, possibilities for the future, and conclusions.

\section{THE ADVANCED COST ACCOUNTING COURSE ${ }^{1}$}

This is an elective course offered to accounting seniors at a large state university with over 1,000 accounting majors. Senior students must have completed all their junior level courses by the time they take their electives. The instructor informs the students at the first lecture that they will need to draw upon their knowledge from courses in economics (two semesters in freshman year) and statistics/decision science (two semesters in junior year). The catalog description of the course reads:

This course covers advanced topics in accounting: strategic profitability analysis; cost allocation and resources; quality and Just-In Time Inventory; and investment decisions and management control.

\footnotetext{
${ }^{1}$ Syllabi, exams, and any other information/material that the reader would like to have are available upon request by contacting the corresponding author.
} 
The advanced cost accounting course was offered in fall and spring semesters and occasionally in summer but has been offered only in spring semesters since 2010. The number of students has varied from 15 to 40 (maximum permitted) when only one section is offered.

Hilton et al. (2008) is the required textbook. The primary course topics are financial and cost-volume-profit models and absorption versus variable costing which appear on the midterm exam. Cost estimation, applying various types of statistical techniques to forecasting sales (where the project comes in), introduction to investor behavior and decision-making, strategic issues in making investment decisions, transfer pricing and organizational design, responsibility accounting, and evaluation of divisional performance appear on the final exam.

The instructor conducts the course in a lecture-discussion format. The class meets one night per week for 15 weeks. The instructor determines grades based on the performance on the mid-term exam (40\%), final exam (45\%), and research project (15\%). The exams consist of problems and essay questions. Questions from the final exam relating to applying various types of statistical techniques to forecast sales and investor behavior and decisionmaking also relates to the project. These topics are usually covered in weeks 10 and 11 of the semester when the instructor discusses the research project and emphasizes the learning objectives of the project.

\section{BACKGROUND FOR THE PROJECT}

Laksmana and Tietz (2008) found empirical evidence that the leading textbooks in cost accounting devote an appreciable amount of space to cost estimation. For example, under the topic of cost estimation (also called determining how costs behave) Horngren et al. (2012, pp. 340-357) discusses five methods: the industrial engineering method, the conference method, the account analysis method, the high-low method, and regression analysis.

However, Horngren et al. (2012) devote the most space to regression analysis. The same extensive coverage and assessment of regression analysis appear in Kinney and Raiborn (2011, pp. 73-78), Blocher et al. (2013, pp. 269-279), and Hilton et al. (2008, pp. 424-435).

The instructor extends the application of regression analysis to sales forecasting which is also mentioned in Blocher et al. (2013, pp. 357-358) and Hilton et al. (2008, pp. 614-615) where they discuss the various approaches to sales forecasting and give prominence to the econometric approaches but without any computational analysis. The forecast of sales growth rates or sales trends is the starting point in setting the operating budget and Blocher et al. (2013, p. 357) warns that "An inaccurate sales forecast can render the entire budget a futile exercise and often imposes costly expenses to the firm as well as the suppliers."

To summarize, the instructor discusses various ways of estimating costs with an extensive focus on regression analysis. When discussing the topic "applying various types of statistical techniques to forecasting sales," the instructor extends regression analysis to sales forecasting which is an important part of budgeting. Students learn about budgeting in one of the prerequisite accounting courses. The advanced cost accounting course introduces students to some of the quantitative methods for forecasting sales.

\section{THE PROJECT}

The instructor introduced this research project in the course in Fall 2009 and has required it in Spring 2010 and every spring since then. He felt it would enhance active learning while integrating the subject matter with macroeconomics and statistics and give the students exposure to real-world data. The instructor observed that students found the subject matter too abstract and conceptual so that the project would help them see how practical some of the course material really was.

Prior to Fall 2009, students form their own teams of two and select a publically-listed company that has at least 20 years of sales and operating income data. Team members compute degree of operating leverage ratios and discuss their findings with the rest of the class (oral presentation) and submit a final report to the instructor. 
In Fall 2009, the instructor decided to integrate a new project in conjunction with the topic titled "applying various types of statistical techniques to forecasting sales" An important aspect is to develop the ability to link data, knowledge, and the insight together from various disciplines to provide information for decision-making. Requiring students to undertake a research project that integrates the knowledge gained from macroeconomics and statistics to sales forecasting is an attempt to develop the core competencies described in the AICPA Framework and the AACSB's Accounting Standard \#37. These represent the fourth and fifth learning objectives, described above.

The instructor introduces the project in week 10 of the semester after the students have completed Cost estimation and an introduction to statistical measures of trend analysis such as arithmetic mean, variance, standard deviation, t-test, coefficient of variation, and geometric mean. The instructor reviews the fundamentals of regression analysis when discussing cost estimation, to explain the practical difficulties of implementing it, and to make the students aware of the underlying assumptions.

Students form their own teams and select a publically-listed company which has at least 16 years of sales data and the relevant macroeconomic data. Reasons for accepting at least 16 years of data as opposed to at least 25 years, which was the number of years the instructor used in Fall 2009 and Spring 2010, is discussed later under "Reflections on Past Semesters." Team members perform a quick search to ensure that the company has sufficient data available and then contact the instructor to have their company approved.

The instructor approves companies on a first-come basis. An important part of the approval process is to ensure that the company selected has a financial year ending during the October 31 to February 28 time period and ideally on December 31 because the macroeconomic data are available only for the calendar year. The instructor allows for the sales data and the macroeconomic data to be mismatched by a maximum of two months so as to allow students to have a broader choice of companies. Forming teams of two ensures that each student is responsible for a significant part of the research project and synergies flow from their respective abilities. The instructor spends ten minutes each week discussing any difficulties that teams are encountering and whether each team member is making a meaningful contribution. Students are encouraged to report problems with their teammates to the instructor, but reports of problems are very rare.

Moderate supervision is essential in guiding the students. The instructor reviews the data presented by the teams to ensure that they are utilizing the appropriate CPI or PPI and macro-economic variables and that the statistical results are plausible. The instructor does not offer direct assistance in interpreting the results or with the written part of the project.

The sales data are readily available from the Wharton Research Data Services paid subscription service. It also should be available on the database at most college libraries and is available at the SEC website at http://www.sec.gov/edgar/searchedgar/webusers.htm. The students acquire the relevant macroeconomic data from the Economic Report of the President. The U.S. Government Printing Office publishes the report, which is freely available at http://www.whitehouse.gov/administration/eop/cea/economic-report-of-the-president. Students must identify and collect: (1) an appropriate price index to express the company's sales in real terms (inflation adjusted) and (2) an appropriate macroeconomic driver such as GDP or PCE or the various components of GDP or PCE expressed in nominal and in real terms.

Using class time to demonstrate how to apply the regression functions in Microsoft Excel and how to interpret the results removes some of the students' anxieties in undertaking the project. The instructor presents the data for Home Depot to illustrate how the project should work (see Appendix 3). Students can convert nominal sales into "real sales" using the producer price index for consumer durable goods (Table B-65 of the Economic Report of the President for 2013), using 2005 as the base year. It does not matter which base year students select because they are examining growth rates in sales and growth rates in the macroeconomic variables and these will be the same irrespective of the base year they chose. The data for personal consumption expenditures for durable goods appear in nominal and real terms (Tables B-16 and B-17 from the 2013 Report). Growth rates in sales and PCE are in nominal and real terms. 
Students analyze and explain the respective means, standard deviations, coefficient of variations, computed t-values, and geometric means. Paquette (2005) shows that geometric mean is a superior measure of past performance than arithmetic mean because the latter tends to overstate the true growth rate when there are significant variations in the growth rates during the period under review.

\begin{tabular}{|c|c|c|c|c|}
\hline & Table 1 & & & \\
\hline \multicolumn{5}{|c|}{ Regression of Sal es Growth Rates and PCE Growth Rates } \\
\hline \multicolumn{5}{|c|}{$(\text { Sales Growth Rates })_{\mathrm{t}}=2.6537 \%+1.9338(\text { PCE Growth Rates })_{\mathrm{t}}$} \\
\hline \multicolumn{5}{|c|}{ SUMMARY OUTPUT } \\
\hline \multicolumn{5}{|c|}{ Regression Statistics } \\
\hline Multiple R & 0.711908739 & & & \\
\hline R Square & 0.506814052 & & & \\
\hline Adjusted R Square & 0.473934989 & & & \\
\hline Standard Error & 0.090002093 & & & \\
\hline Observations & 17 & & & \\
\hline \multicolumn{5}{|l|}{ ANOVA } \\
\hline & $d f$ & $S S$ & $M S$ & $F$ \\
\hline Regression & 1 & 0.124863191 & 0.124863191 & 15.4144919 \\
\hline Residual & 15 & 0.121505651 & 0.008100377 & \\
\hline \multirow{2}{*}{ Total } & 16 & 0.246368842 & & \\
\hline & Coefficients & Standard Error & $t$ Stat & P-value \\
\hline Intercept & 0.026537266 & 0.029416314 & 0.902127494 & 0.38124709 \\
\hline $\mathrm{X}$ Variable 1 & 1.933826531 & 0.492552931 & 3.926129375 & 0.00134749 \\
\hline
\end{tabular}

Table 1 shows the results of regressing sales growth rates to PCE growth rates. The constant coefficient, representing the long term trend for Home Depot's sales, is not statistically significant and can be set to zero (this is the fixed cost element in cost estimation). The instructor discusses the various implications of the regression results if the constant coefficient is statistically significant and if the slope coefficient is not statistically significant. 


\begin{tabular}{|c|c|c|c|c|}
\hline & Table 2 & & & \\
\hline \multicolumn{5}{|c|}{ Regression of Real Sal es Growth Rates and Real PCE Growth Rates } \\
\hline \multicolumn{5}{|c|}{$(\text { Real Sales Growth Rates })_{t}=-2.5407 \%+2.0140(\text { Real PCE Growth Rates })_{t}$} \\
\hline \multicolumn{5}{|c|}{ SUMMARY OUTPUT } \\
\hline \multicolumn{5}{|c|}{ Regression Statistics } \\
\hline Multiple R & 0.740937832 & & & \\
\hline R Square & 0.54898887 & & & \\
\hline Adjusted R Square & 0.518921462 & & & \\
\hline Standard Error & 0.089647718 & & & \\
\hline Observations & 17 & & & \\
\hline \multicolumn{5}{|l|}{ ANOVA } \\
\hline & $d f$ & $S S$ & $M S$ & $F$ \\
\hline Regression & 1 & 0.146739156 & 0.146739156 & 18.2586028 \\
\hline Residual & 15 & 0.1205507 & 0.008036713 & \\
\hline \multirow[t]{2}{*}{ Total } & 16 & 0.267289856 & & \\
\hline & Coefficients & Standard Error & $t$ Stat & P-value \\
\hline Intercept & -0.02540674 & 0.035830361 & -0.70908413 & 0.48914772 \\
\hline $\mathrm{X}$ Variable 1 & 2.01400029 & 0.471330733 & 4.27300863 & 0.00066708 \\
\hline
\end{tabular}

Table 2 shows the results of regressing real sales growth rates to real PCE growth rates (similar results as in Table 1). In summary, the instructor gives the students the Appendix and Tables 1 and 2 for Home Depot in Microsoft Excel format.

The students prepare tables for their company and submit a minimum of three pages (double spaced) discussing their results. They devote a maximum of one-half page to discussing the background of the company they selected. Students should relate the discussion regarding annual sales and macroeconomic data to the choice of CPI or PPI they made and to the macroeconomic variables they selected. Students also should discuss the growth rates in nominal and real sales and the significance of the means, standard deviations, coefficient of variations, computed tvalues, and geometric means. Students must provide an extensive explanation of the regression results from Tables 1 and 2 and must relate the results to their statistical data. Teams submit a hard copy of the research project and an electronic version of their data so the instructor can verify their results. The research projects are due at the last class of the semester when the instructor once again discusses the learning objectives of the project. Students have commented informally to the instructor that the project is very challenging, but rewarding in that it assists them in integrating the knowledge gained from their economics and statistics courses in a meaningful way to accounting and financial decision making. Grading of the project reveals that the majority of the teams understood the concepts and appropriately interpreted their statistical results. Questions on the final exam further help the instructor to determine 
whether the learning objectives have been achieved. Students were encouraged to complete a questionnaire about the research project in Spring 2013, and the results are discussed below. In grading the project, the instructor allocated $20 \%$ for the computations presented in the tables, $60 \%$ for technical analysis of the results, and $20 \%$ for the composition of the paper (grammar, spelling, and logical flow.) In Spring 2012, the instructor received 11 projects, and the class average was $71 \%$ (which is a $\mathrm{C}$ grade) with a standard deviation of $11.24 \%$. Students achieved similar results in Spring 2013. The instructor received 18 projects, and the class average was $72 \%$ (which is a $\mathrm{C}$ grade) with a standard deviation of $11.36 \%$. In both years, some of the teams did not spend sufficient time relating their regression results to the Management Discussion and Analysis (MD\&A) presented in the company's financial reports and to reports issued by financial analysts.

\section{STUDENTS FEEDBACK FROM QUESTIONNAIRE IN SPRING 2013}

Students were given an opportunity to complete a questionnaire online after the research project was submitted for extra credit. A faculty member in the Department monitored which students completed the questionnaire and submitted the information to the instructor so that credit could be given to the students. The contents of the questionnaire were available to the instructor after the course grades were posted. Twenty-eight of the thirty-six students completed the questionnaire (77.8 percent). The questionnaire posed four questions:

1) List and discuss the challenges you faced in completing your research project;

2) How can the requirements for the research project be changed to enhance the benefit(s) that you may derive from completing the research project;

3) List three things (if any) you liked about the research project; and

4) List three things (if any) that you disliked about the research project.

Some interpreted the first question in positive terms, others negatively. As a result, the responses to what they liked (Question \#3) and disliked (Question \#4) were not mutually exclusive from the first question. Question \#2 asked for recommendations for future changes in the project requirements. Those responses also were not always distinct from the other comments.

In general, it appeared the students believe the project is a positive experience. The comments related primarily to ways the instructor can enhance the project assignment. One overall impression of the responses was that students would have liked the instructor to provide materials and explanations so the students would not have to interpret the results and not have to think critically. The instructor needs to emphasize at the outset that the project requires independent thinking that mirrors the kind of experiences students will encounter in the work place. Such an explanation will justify the approach and help the students appreciate its relevance to their future endeavors.

The vast majority of the 28 respondents really liked applying the knowledge they gained in the course and, in particular, applying it to real world data. They liked applying Excel and using knowledge they gained from other courses. Many appeared frustrated by their inability to identify companies stable enough to reach the $40 \% \mathrm{R}^{2}$ threshold. Some would have preferred to select a company from a list the instructor provided, all of which met the threshold. However, some were happy to choose their own companies and comfortable with the challenge of identifying an acceptable one. The instructor needs to discuss the company selection process in a way that prepares the students for this experience and explains why it is important for them to be confronted by this issue. Many liked selecting their own partner, as opposed to having one assigned. Some would have preferred to work alone. It may be desirable for the instructor to explain the importance of working on teams in a work environment. Quite a few mentioned the difficulty of finding time to meet with their partner, a situation quite typical of an urban, commuter institution. Several liked working with the Wharton database and felt exposure to it was a positive experience. A number of suggested changes related to more instructor guidance. Students would like class time devoted to learning how to interpret the data and how to address the issue of companies with $\mathrm{R}^{2}$ less than $40 \%$.

\section{REFLECTIONS ON PAST SEMESTERS}

As mentioned earlier, the instructor introduced this research project in Fall 2009 and required it in Spring 2010, Spring 2011, Spring 2012, and Spring 2013. The instructor placed greater emphasis on data gathering and the 
computational aspects of the project in Fall 2009 and Spring 2010, and students were required to have at least 25 years of data (the previous projects that dealt with the computation and analysis of degree of operating leverage required at least 20 years of data). For Fall 2009 and Spring 2010 the instructor allocated 25\% for the computations presented in the tables, $50 \%$ for technical analysis of the results, and 25\% for the composition of the paper (grammar, spelling, and logical flow.) because the requirement to have at least 25 years of data meant that students spent more time on data gathering. The relevant macroeconomic data from the Economic Report of the President in some cases is limited to 16 years or less and required additional complex computations when a longer period is studied. One way of obtaining statistically significant results is to have a large sample size but the data may not be homogenous over the entire period. The instructor required at least 25 years of data for Fall 2009 and Spring 2010, but students found it very challenging to integrate the macro-economic data from the different Economic Reports and the instructor ended up doing the computations for the students. Due to the above difficulties that students encountered, the instructor required at least 16 years of data in Spring 2011, Spring 2012, and Spring 2013, but placed greater emphasis on the interpretation of results: $20 \%$ for the computations presented in the tables, $60 \%$ for technical analysis of the results, and $20 \%$ for the composition of the paper (grammar, spelling, and logical flow).

The instructor provides the required mathematical and statistical formulas as an Excel template, so the students only have to input the data for their company. Their challenge is to interpret their results. Students thereafter complete the regressions and explain their results. The authors will make available upon request the Excel templates for Home Depot so that other instructors can review the formulas.

Quite often the $\mathrm{R}^{2}$ statistic is very weak (less than $10 \%$ ) which may be due to one or two outliers. Rerunning the regression without the outliers significantly improves the results. The teams must investigate the outliers which usually are due to mergers, acquisitions, and spin-offs that affect the reported revenues whereas the macroeconomic variable is fairly stable. The students reporting low $\mathrm{R}^{2}$ values must produce a table showing regression residuals. Students have to review this table to identify outliers which they could remove from the data set and conduct a new regression.

\section{POSSIBILITIES FOR THE FUTURE}

Instructors could expand the research project by regressing sales growth rates to growth rates in the macroeconomic variable with a one-period lag. Multinational companies, such as IBM, Motorola, Coca-Cola, PepsiCola, and McDonalds operate in many countries and derive substantial revenues from non-U.S. sources. A review of the Wall Street Journal or any other business publication shows that the U.S. economy tends to lead the economies of their major trading partners by six months to one year. The one-period lag could capture the delayed impact of non-U.S. revenues on the performance of the U.S. multinational companies. Forming teams of two ensures that each student is responsible for a significant part of the research project and synergies flow from their respective abilities. Students are encouraged to report problems with their teammates to the instructor, but reports of problems are very rare. However, instead of relying on students to voluntarily report to the instructor any problems with their teammates, a formal system of confidential written peer-reviews could be implemented and average scores on the peer evaluations could be incorporated in the final grade for the project. This would also help prevent "free riders" in the data collection and regression analyses portions of the project.

\section{CONCLUSIONS}

The authors believe that the research project provides an active learning experience and forces students to integrate their knowledge from others courses (in this case, macroeconomics and statistics) with cost accounting. By using real-world data students gain exposure to practical issues they may encounter after graduation. These are the kind of opportunities the AICPA Core Competencies and the AACSB Accounting Accreditation Standard \#37 are encouraging. The research project expands the use of regression analysis beyond the area of cost estimation by relating sales growth rates to appropriate macroeconomic variables, introducing students to various other statistical measures of sales growth rates, and developing an appreciation of how inflation may impact the derived statistical results. Informal student feedback about the project has been strongly favorable although they find it very challenging but rewarding in that it assists them in integrating the knowledge gained from their economics and statistics courses in a meaningful way to accounting and financial decision making. 


\section{AUTHOR INFORMATION}

Mahamood M. Hassan, Ph.D., is a professor of accounting at California State University, Fullerton over the past 25 years. His primary teaching has been cost/managerial accounting at the introductory and advance level to both undergraduates and graduates. He has published articles in various journals relating to finance. He previously taught at the University of Cape Town. He has been a member of the South African Institute of Chartered Accountants (SAICA) since 1977. He received his doctorate in finance from the University of Arizona in 1989, an MS in finance from Arizona in 1983, and a Bachelor of Commerce (Honors) in accounting from the University of Cape Town in 1973. E-mail: mmhassan@ fullerton.edu (Corresponding author)

Bill N. Schwartz, Ph.D., CPA, is a retired accounting professor. He earned his doctorate at UCLA in 1978. He served on the faculties of Arizona State University, Temple University, Virginia Commonwealth University (where he also served as Department Chair), Indiana University-South Bend (where he served as Dean of the School of Business), and Stevens Institute of Technology (as Distinguished Affiliate Professor). He is a past Chair of the Teaching and Curriculum Section of the American Accounting Association. He is currently a visiting faculty member at the Swiss Business School in Zurich, Switzerland. E-mail: $\underline{\text { bschwartz1945@ comcast.net }}$

\section{REFERENCES}

1. American Institute of Certified Public Accountants (AICPA). (1999). AICPA Core Competency framework for entry in to the accounting profession. Available from http://www.aicpa.org/interestareas/accountingeducation/resources/pages/corecompetency.aspx

2. Baril, C., Betancourt, L., \& Briggs, J. (2007). Valuing employee stock options under SFAS 123R using the Black-Scholes-Merton and lattice model approaches. Journal of Accounting Education, 25, 88-101.

3. Blocher, E. J., Stout, D. E., Juras, P. E., \& Cokins, G. (2013). Cost management: A strategic emphasis $\left(6^{\text {th }}\right.$ ed.). New York, NY: McGraw-Hill Irwin.

4. Brenner, V. C., \& Watkins, A. L. (2011). Introducing students to the FASB Codification System. The Accounting Educators' Journal, 153-171.

5. Briggs, J. W., \& Beams, J. D. (2012). Securitization of assets: An accounting and finance case. The Accounting Educators' Journal, 25-42.

6. Chiang, B. (2008). Integrating a service-learning project into management accounting coursework - A sharing of implementation experience and lessons learned. Accounting Education: An International Journal, 17(4), 431-445.

7. Danvers, K., \& Brown, C. A. (2009). Out-West Products, Inc.: A financial modeling and decision analysis case. Journal of Accounting Education, 27, 40-57.

8. Dikoli, S. S., \& Sedatole, K. L. (2004). Delta's new song: A case on cost estimation in the airline industry. Issues in Accounting Education, 19(3), 345-358.

9. Economic Report of the President. (2012). Available from http://www.whitehouse.gov/administration/eop/cea/economic-report-of-the-president

10. Friedman, M., Rushinek, A., \& Rushinek, S. (2006). The effect on achievement of using emerging technology in the managerial accounting course. The Accounting Educators' Journal, 25-40.

11. Hilton, R. W., Maher, M. W., \& Selto, F. H. (2008). Cost management: Strategies for business decisions (4th ed.). New York, NY: McGraw-Hill Irwin.

12. Hoffjan, A. (2005). Calvados - A business game for your cost accounting course. Issues in Accounting Education, 20(1), 63-80.

13. Horngren, C. T., Datar, S. M., \& Rajan, M. (2012). Cost accounting - A managerial emphasis (14 ${ }^{\text {th }}$ ed.). Upper Saddle River, NJ: Pearson Prentice Hall.

14. Kinney, M. R., \& Raiborn, C. A. (2011). Cost accounting - Foundations and evolutions ( $8^{\text {th }}$ ed.). Mason, Ohio: South-Western Cengage Learning.

15. Laksmana, I., \& Tietz, W. (2008). Temporal, cross-sectional, and time-lag analysis of managerial and cost accounting textbooks. Accounting Education: An International Journal, 17(3), 291-312.

16. Paquette, L. R. (2005). Growth rates as measures of financial performance. Journal of Accounting Education, 23, 67-78. 
17. Platt, D. E., \& Towry, K. L. (2001). Pecos Products: A project introducing complexity into the study of activity-based costing. Issues in Accounting Education, 16(1), 99-124.

18. Securities Exchange Commission (SEC). Available from http://www.sec.gov/edgar/searchedgar/webusers.htm

19. Stout, D. E., West, R. N., \& Liberatore, M. J. (2004). Project management: A core competency in managerial accounting education. Management Accounting Quarterly, 5(4), 53-61.

20. Swain, M., Charles, S., Hobson, S., Stocks, K., \& Pratt, C. (2010). Managing the CPA firm at Dodge Company, 'Shoeing the cobbler's children.' Issues in Accounting Education, 25(4), 721-739.

21. The Association to Advance Collegiate Schools of Business International (AACSB). Available from http://www.aacsb.edu/accreditation/accounting/standards/STANDARDS-accntg-jan2012.pdf

22. Theuri, P. M., Greer, B. M., \& Turner, L. D. (2011). The efficacies of utilizing a multimedia based instructional supplement on learners' cognitive skills. The Accounting Educators ' Journal, 107-129.

23. Wharton Research Data Services. Available from https://wrds-web.wharton.upenn.edu/wrds/ 


\begin{tabular}{|c|c|c|c|c|c|c|}
\hline & & & Appendix & & & \\
\hline & & & Section 1 & & & \\
\hline & & \multicolumn{4}{|c|}{ Home Depot's Annual Sales and Macroeconomic Data } & \\
\hline Year $^{1}$ & $\begin{array}{l}\text { Nominal } \\
\text { Sales }^{2}\end{array}$ & $\mathbf{P P I}^{3}$ & Real Sales ${ }^{4}$ & Nominal $\mathbf{P C E} \mathbf{E}^{5}$ & Real $P_{C E}{ }^{6}$ & $\begin{array}{l}\text { Implicit Price } \\
\text { Deflator }^{7}\end{array}$ \\
\hline 1995 & 15470.358 & 132.7 & 15925.026 & 635.70 & 510.50 & 124.52 \\
\hline 1996 & 19535.503 & 134.2 & 19884.871 & 676.30 & 548.60 & 123.28 \\
\hline 1997 & 24156.000 & 133.7 & 24679.952 & 715.50 & 593.30 & 120.60 \\
\hline 1998 & 30219.000 & 132.9 & 31060.312 & 780.00 & 665.60 & 117.19 \\
\hline 1999 & 38434.000 & 133.0 & 39474.319 & 857.40 & 752.00 & 114.02 \\
\hline 2000 & 45738.000 & 133.9 & 46660.275 & 915.80 & 818.00 & 111.96 \\
\hline 2001 & 53553.000 & 134.0 & 54592.088 & 946.30 & 862.40 & 109.73 \\
\hline 2002 & 58247.000 & 133.0 & 59823.611 & 992.10 & 927.90 & 106.92 \\
\hline 2003 & 64816.000 & 133.1 & 66520.403 & 1019.90 & 989.10 & 103.11 \\
\hline 2004 & 73094.000 & 135.0 & 73960.299 & 1072.90 & 1060.90 & 101.13 \\
\hline 2005 & 81511.000 & 136.6 & 81511.000 & 1123.40 & 1123.40 & 100.00 \\
\hline 2006 & 90837.000 & 136.9 & 90637.942 & 1155.00 & 1174.20 & 98.36 \\
\hline 2007 & 77349.000 & 138.3 & 76398.217 & 1188.40 & 1232.40 & 96.43 \\
\hline 2008 & 71288.000 & 141.2 & 68965.586 & 1108.90 & 1171.80 & 94.63 \\
\hline 2009 & 65955.000 & 144.3 & 62435.572 & 1029.60 & 1109.30 & 92.82 \\
\hline 2010 & 67997.000 & 144.9 & 64102.072 & 1079.40 & 1178.30 & 91.61 \\
\hline 2011 & 70305.000 & 147.4 & 65153.752 & 1146.40 & 1262.20 & 90.83 \\
\hline 2012 & 74754.000 & 151.0 & 67625.142 & 1219.10 & 1361.00 & 89.57 \\
\hline \multicolumn{7}{|c|}{1 Home Depot's financial year end is the last Sunday closest to January 31st, thus 1995} \\
\hline \multicolumn{4}{|c|}{ refers to the last weekend in January 1996.} & & & \\
\hline \multicolumn{6}{|c|}{2 Sales in millions of dollars from Wharton Research Data Services which is at } & \\
\hline \multicolumn{3}{|c|}{ http://wrds.wharton.upenn.edu. } & & & & \\
\hline \multicolumn{7}{|c|}{3 Economic Report of the President (2013): Producer Price Index for Consumer Durable } \\
\hline \multicolumn{2}{|c|}{ Goods (Table B-65). } & & & & & \\
\hline \multicolumn{4}{|c|}{4 Real Sales using 2005 as the base year (136.6). } & & & \\
\hline \multicolumn{7}{|c|}{5 Economic Report of the President (2013): Personal Consumption Expenditure on Durable } \\
\hline \multicolumn{4}{|c|}{ Goods in billions of dollars (Table B-16) } & & & \\
\hline \multicolumn{7}{|c|}{6 Economic Report of the President (2012): Real Personal Consumption Expenditure on } \\
\hline \multicolumn{4}{|c|}{ Durable Goods in 2005 dollars (Table B-17) } & & & \\
\hline 7 Implici & Deflator $=$ & Nominal P & / Real PCE) $x$ & & & \\
\hline
\end{tabular}




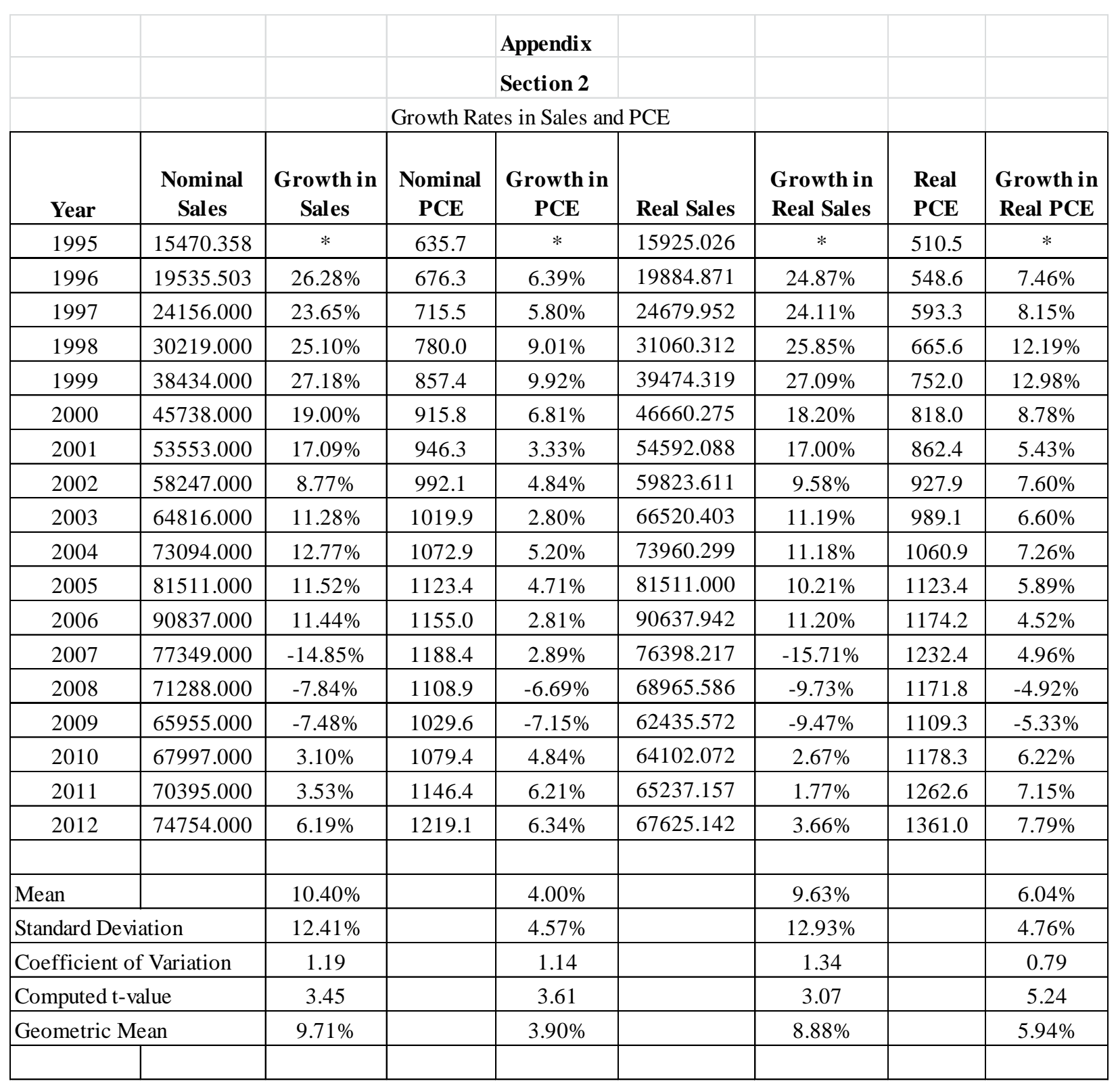

